\title{
Impact of BRAC and PDBF sponsored homestead vegetables programme on the socio-economic development of rural women in Mymensingh district
}

\author{
M. Rahman ${ }^{1}$, K. Naher ${ }^{2}$, R.H. Sarwer ${ }^{3}$ and M.Z. Huda ${ }^{4}$ \\ ${ }^{1}$ Planning \& Evaluation Division, BRRI, Gazipur \\ ${ }^{2}$ Grameen Krishi Foundation (GKF), Alam nagar, Rangpur \\ ${ }^{3}$ BSERT, Bangladesh Agricultural University, Mymensingh \\ ${ }^{4}$ Premier Bank Ltd., Head Office, Dhaka
}

\begin{abstract}
A study was carried out at four thanas namely, Mymensingh sadar, Muktaghacha, Trishal, and Bhaluka of Mymensingh district to assess impact of BRAC and PDBF sponsored homestead vegetable programme on household income and socio-economic development of rural women. A total of 40 women were involved in vegetable programme as 20 under each BARC and PDBF sponsored households. Purposive sampling technique was followed to select the samples of the study. Vegetable enterprise under both BRAC and PDBF had positive impact on increasing household income. Per household gross margin of vegetable production under BRAC (Tk 1864) was slightly higher than PDBF households (Tk 1745). But per 'Taka' return from vegetable under PDBF households (3.86) was higher than that of BRAC households (3.71). Women's age and education, family land ownership, total number of family members and also number of earning members had significant positive impact on household income. Except marketing, women performed all other activities required for growing vegetables and thus contributed to family income. Vegetable enterprise created an employment for women as they utilized a total of 252 hours year ${ }^{-1}$ in both PDBF and BRAC households in different activities needed for it. Collection of good seeds and unsatisfactory prices of seeds are the major problems of growing vegetables.
\end{abstract}

Key words: BRAC, PDBF, Homestead vegetable programme, Household income, Socio-economic development, Rural women

\section{Introduction}

A vast majority (58\%) of the rural population in Bangladesh lives below poverty line (OXFORD, 2000). They are economically underprivileged, socially deprived and deeply exploited. Further, despite playing substantial role in the family and in the national economy, rural women are seriously deprived of their privileges in the family and national life. Thus, female poverty in Bangladesh is visible in their low level of education, poor health, unpaid or less paid jobs and inadequate income. Poverty has been identified as a major problem and its alleviation has been stated as an important objective in all the national plan documents of Bangladesh. Different poverty alleviation programmes deal with improvement of the quality life of the poor through promotion of viable economic and social activities under various government and non-government organizations. The burden of poverty falls differently not only among various socio-economic classes, but also on different sex groups. Thus different poverty alleviation programmes are undertaken to address regional as well as gender dimensions of poverty.

There are both government and non-government organizations implementing Rural Development Programmes (RDPs) for alleviating poverty and of course, development of rural areas all over the country. For example, PDBF (Palli Daridra Bimochon Foundation), a government organization, has been established with a view to alleviating poverty and stimulating economic and social development of the poorer segment of population. It acts as an autonomous, non-banking financial institution. It is a non-profit motive foundation, the aim 
of which is to serve the society (GOB, 1999). On the other hand, BRAC (Bangladesh Rural Advancement Committee), one of the leading NGOs in Bangladesh, has organized over 3.3 million landless people into 90,250 village organizations (VOs) under RDP since its inception in 1976. BRAC organizes the poor and provides them credit, training, and other necessary support through its village organizations. BRAC believes that micro-credit is an important tool for breaking the poverty cycle. It also places equal importance on training its members' income generating activities and facilitating linkages with the consumer markets in Bangladesh. (BRAC, 1999).

Majority (49.58\%) of the farmers own small land holdings (0.1-1.0 ha) including the homestead in rural Bangladesh (BBS, 2005). They have to utilize their scarce resource properly for livelihood. For this purpose, they also have to utilize and/or develop homestead enterprises to generate additional income. In fact, homestead enterprises are commonly managed by women counterpart of the farm families as found in most of the socio-economic researches. Considering the fact, both GOs and NGOs like PDBF and BRAC are providing small credit to women in terms of cash or kind for increasing homestead production and thereby increase income. They are also providing technical assistance and regular supply of necessary inputs. In this way, PDBF and BRAC are playing an important role for improving socio-economic condition of rural women through involving them in generating or increasing household income.

Little attempts had been made so far to make an in-depth investigation in respect of assessment of RDP like vegetables programme under BRAC and PDBF. Haque (1998) found that there was enough potentiality to generate income from livestock, poultry and sericulture programme under BRAC. She also mentioned that income of households under BRAC programme from sale of vegetables, poultry and livestock products and agricultural employment increased substantially in the area. Rahman (1998) reported that the annual income per household of poultry, dairy and sericulture groups of BRAC were Tk. 23388, Tk. 31881 and Tk. 32607, respectively. Findings also revealed that consumption of rice, cloths, cost of health care increased by $51,183,165$ per cent, respectively. Thus assessing the impact of RDP like homestead vegetable programme was necessary to know success of the programme in raising the socio-economic status of rural women. Findings of the study would be of immense use to practitioners and policy makers working in the field of rural development and women in development. Hence, the present study was a modest attempt to measure the profitability of BRAC and PDBF sponsored homestead vegetable programme and its impact on household income, assess women's participation and employment pattern in vegetable enterprise and identify problems associated with vegetable enterprise and the probable solutions.

\section{Materials and Methods}

The study was carried out at twenty selected villages under four thanas namely, Mymensingh sadar, Muktagacha, Trishal and Bhaluka of Mymensingh district during July to November 2000. Purposive sampling technique was used in selecting sample of the study. A total of 40 sample households were selected for the study, of which, 20 households were involved in BARC-sponsored vegetable programme while rest 20 households were under PDBF. Thus 40 rural women from selected households (involved in vegetable programme under BRAC and PDBF) constituted sample of the study. Pre-tested interview schedule was used as a tool for collecting data. After collection, data were checked, crosschecked, compiled, tabulated and analysed as per objective of the study. Statistical tools such as, percentage, ratio were used. Besides, multiple regression analysis was done to measure the quantitative impacts of some selected variables on the household income. 


\section{Functional Analysis}

In order to explore the effects of different socio-economic attributes on income of the household, different types of theoretical plausible relationship were examined. Multiple regression function was chosen on the basis of the theoretical background. Age and educational status of the respondents were considered to have impact on the household income. It was also assumed that there exist a positive relationship between income and ownership of land. The duration of membership of the households was also considered to have positive effect on household income. Intercept dummy was introduced in the empirical model to identify contribution of different qualitative factors.

On the basis of these assumed conditions, the multiple regression function was specified in order to examine the variation in income as a result of one unit variation in the influencing factor. The general specification of the function was as follows.

$$
Y=f\left(X_{1}, X_{2}, X_{3}, X_{4}, X_{5}, X_{6}, D_{1}\right)
$$

Where, $Y=$ Total annual income of the household;

$\mathrm{X}_{1}=$ Age of the respondent; $\mathrm{X}_{2}=$ Education of the respondent; $\mathrm{X}_{3}=$ Period of membership; $. X_{4}=$ Ownership of land; $X_{5}=$ Number of members in the family; $X_{6}=$ Number of earning members in the family; $D=$ Dummy variable for organizational effect; where, $D=1$ for BRAC member and 0 otherwise

By applying the theoretical model, the empirical model with dummy for organizational effect was specified as:

$$
Y=a+b_{1} X_{1}+b_{2} X_{2}+b_{3} X_{3}+b_{4} X_{4}+b_{5} X_{5}+b_{6} X_{6}+b_{7} D
$$

\section{Results and Discussion}

\section{Cost and Return Analysis}

It is evident from Table 1 that cost for 'trail' or 'macha' is the major cost item for vegetable cultivation in the homestead. The cost for trail (Tk. 449 year $^{-1}$ ) in BARC household was significantly higher than PDBF households (Tk. 385 year $^{-1}$ ). Cost for seeds, fertilizer and insecticide was more or less same. However, total cost for vegetable cultivation in BARC households was $10.95 \%$ higher than that of PDBF households (Table 1).

Table 1. Cost of vegetable cultivation by BRAC and PDBF households

\begin{tabular}{|l|c|c|c|c|c|}
\hline \multirow{2}{*}{ Materials } & \multicolumn{2}{|c|}{ Cost per household ${ }^{-1}$ year (Tk) } & \multicolumn{3}{c|}{$\begin{array}{c}\text { Difference between } \\
\text { BRAC \& PDBF households }\end{array}$} \\
\cline { 2 - 5 } & BRAC & PDBF & Absolute & t-values & Percentage \\
\hline 1. Seed & $73(10.6)$ & $76(12.3)$ & 3 & 0.29 & 4.17 \\
\hline 2. Fertilizer & $98(14.2)$ & $84(13.8)$ & 14 & 1.10 & 14.43 \\
\hline 3. Insecticide & $65(09.5)$ & $65(10.7)$ & 0 & - & - \\
\hline 4. 'Trail' or 'Macha' & $449(65.7)$ & $385(63.2)$ & 64 & $2.09^{*}$ & 14.44 \\
\hline Total & $\mathbf{6 8 5 ( 1 0 0 )}$ & $\mathbf{6 1 0 ( 1 0 0 )}$ & $\mathbf{7 5}$ & - & $\mathbf{1 0 . 9 5}$ \\
\hline
\end{tabular}

Figure in parentheses indicates percentage

*Significant at $5 \%$ level

The average gross return (Tk. 2549 year $^{-1}$ ) in BRAC households was higher than PDBF households (TK. 2355 year $^{-1}$ ). BARC households consumed more and sold less amount of vegetables compared to PDBF households (Table 2). Though gross margin (TK. 1864 year $^{-1}$ ) obtained in BRAC households was higher than PDBF households (Tk. 1745 year $^{-1}$ ) but return $\mathrm{Taka}^{-1}$ from PDBF households was higher than that of BRAC households (Table 2). 
Table 2. Cost and Return analysis for vegetable enterprise in BRAC and PDBF households

\begin{tabular}{|l|c|c|}
\hline \multirow{2}{*}{ Return items } & \multicolumn{2}{|c|}{ Average per household per year (Tk.) } \\
\cline { 2 - 3 } & BRAC households & PDBF households \\
\hline Sold & 1228 & 1383 \\
\hline Family consumption & 1321 & 972 \\
\hline Gross return & 2549 & 2355 \\
\hline Total variable cost & 685 & 610 \\
\hline Gross margin & 1864 & 1745 \\
\hline Return per Taka invested in livestock & 3.71 & 3.86 \\
\hline
\end{tabular}

\section{Determinants of Household Income}

According to empirical model as mentioned in the methodology, agency wise income determination was done. The coefficients and related statistics of the estimated model are presented in Table 3. The variable "age" of the respondent had a significant positive impact on household income. The value of coefficient for age (226.1) implies that the rate of change in the income as a result of change in age by one year was 226.1 and it was significant at $5 \%$ level. The variable "education" of the respondents showed significant positive impact on household income. Findings showed that one unit increment in year of schooling would increase income by Tk. 1343/-. "Ownership of land" also had significant positive role on household income and the coefficient was 67.69. It means one unit increment in land ownership would increase income by Tk. 67.69. Similarly, the variables "number of family members" and "number of earning members" both had significant and positive effect on house income. However, the value of $\mathrm{R}^{2}$ indicated that variables included in the model explained 70 per cent variation in the income level of the sample households (Table 3 ). Thus $\mathrm{R}^{2}$ could be taken as reasonably high coefficient of determination. The measure of the overall fit of the estimated regression function, F-value was significant at $1 \%$ level implies that inclusion of the variables for explaining the variation of household income was reasonably accurate.

Table 3. Estimated coefficient of factors influencing household income and related statistics of the multiple regression function

\begin{tabular}{|l|c|c|}
\hline Variable & Coefficient & t-value \\
\hline Age & $226.1^{\star}$ & 1.98 \\
\hline Education & $1342.67^{\star \star}$ & 3.23 \\
\hline Ownership of land & $67.69^{\star \star}$ & 3.50 \\
\hline Number of family members & $7754.26^{\star \star}$ & 4.33 \\
\hline Number of earning members & $4641.31^{\star \star}$ & 5.04 \\
\hline $\mathrm{R}^{2}$ & 0.70 & \\
\hline F-value & $53.95^{\star \star}$ & \\
\hline
\end{tabular}

*significant at $5 \%$ level; and ** significant at $1 \%$ level 


\section{Women's Participation and Employment Pattern in Vegetable Enterprise}

In the present study, emphasis was given on employment generation for women through vegetable enterprise. To define the situation, various activities were determined primarily and then time was allocated to those activities accordingly. It is evident from Table 4 that except marketing, all other activities needed for homestead vegetable production were performed by women. Time utilization varied depending on item of work between BRAC and PDBF households. Women utilized highest time in harvesting vegetables (73 to $84 \mathrm{hrs}^{\text {year }}{ }^{-1}$ ) followed by land preparation (60 to $62 \mathrm{hrs} \mathrm{year}^{-1}$ ). However, total time utilization in homestead vegetable production by women of BRAC and RDBF households was equal ( $\left.252 \mathrm{hrs} \mathrm{year}^{-1}\right)$.

Table 4. Labour employment pattern in vegetable enterprise

\begin{tabular}{|l|c|c|c|c|c|c|}
\hline \multirow{3}{*}{ Item } & \multicolumn{6}{|c|}{ Work per year (hours) } \\
\cline { 2 - 7 } & \multicolumn{2}{|c|}{ BRAC households } & \multicolumn{2}{c|}{ PDBF households } & $\begin{array}{c}\text { Difference between BRAC and } \\
\text { PDBF }\end{array}$ \\
\cline { 2 - 7 } & Male & Female & Male & Female & Male & Female \\
\hline Land preparation & - & 62 & - & 60 & - & $02(0.50)$ \\
\hline Seeding & - & 24 & - & 29 & - & $05(0.21)$ \\
\hline Fertilizing & - & 30 & - & 31 & - & $01(1.29)$ \\
\hline Harvesting & - & 84 & - & 73 & - & $11(0.15)$ \\
\hline Storing & - & 52 & - & 59 & - & $07\left(2.37^{*}\right)$ \\
\hline Marketing & 216 & - & 210 & - & $06(0.47)$ & - \\
\hline Total & 216 & 252 & 210 & 252 & & \\
\hline
\end{tabular}

Figure in parentheses indicates the t-value of the differences

** indicates that $\mathrm{t}$-value was significant at $1 \%$ level

\section{Problems Associated with Vegetable Enterprise and Suggested Solutions}

Respondents of both BRAC and PDBF households mentioned a number of problems as they faced in growing vegetables (Table 5). They also suggested some solutions to those problems. Majority (33\%) of total respondents mentioned the problem "incidence of diseases" and "unsatisfactory price" and as such both was ranked with $1^{\text {st }}$ position whereas the problem "collection of good seed" occupied $2^{\text {nd }}$ position. However, the problem "preparation and maintenance of macha" was mentioned by lowest percent (5\%) of respondents and attained the lowest position (Table 5).

Table 5. Problems associated with vegetable enterprise as mentioned by the respondents

\begin{tabular}{|l|c|c|c|c|}
\hline \multirow{2}{*}{ Problems } & \multicolumn{4}{|c|}{ No. of citation } \\
\cline { 2 - 5 } & $\begin{array}{c}\text { BRAC } \\
\text { households }\end{array}$ & $\begin{array}{c}\text { PDBF } \\
\text { households }\end{array}$ & Total & Rank \\
\hline 1. Collection of good seed & $9(24)$ & $8(38)$ & $17(29)$ & $2^{\text {nd }}$ \\
\hline 2. Incidence of disease & $14(38)$ & $5(24)$ & $19(33)$ & $1^{\text {st }}$ \\
\hline 3. Preparation \& maintenance of 'macha' & $3(8)$ & 0 & $3(5)$ & $3^{\text {rd }}$ \\
\hline 4. Unsatisfactory price & $11(30)$ & $8(38)$ & $19(33)$ & $1^{\text {st }}$ \\
\hline Total & $37(100)$ & $21(100)$ & $58(100)$ & \\
\hline
\end{tabular}

Figure in parentheses indicates percentage 
According to majority (51\%) of the respondents, smooth supply of good seeds was more important for successful vegetable production (Table 6). About $49 \%$ of the respondents opined that satisfactory price of the produces to be ensured for expanding vegetable production.

Table 6. Suggested solutions as mentioned by the respondents

\begin{tabular}{|l|c|c|c|}
\hline \multirow{2}{*}{ Solutions } & \multicolumn{3}{|c|}{ No. of citation } \\
\cline { 2 - 4 } & $\begin{array}{c}\text { BRAC } \\
\text { households }\end{array}$ & $\begin{array}{c}\text { PDBF } \\
\text { households }\end{array}$ & Total \\
\hline 1. Smooth supply of good seeds & $9(47)$ & $08(50)$ & $17(49)$ \\
\hline 2. Satisfactory prices of products & $10(53)$ & $08(50)$ & $18(51)$ \\
\hline Total & $19(100)$ & $16(100)$ & $35(100)$ \\
\hline
\end{tabular}

Figure in parentheses indicates percentage

\section{Conclusion}

On the basis of the findings of the study it may be concluded that, both BRAC and PDBF sponsored homestead vegetables programme has positive impact on household income. The average return from vegetables under BRAC sponsored households was higher compared to PDBF households. Women are able to contribute some income to their family through homestead vegetable production provided they get financial and technical assistance from GOs or NGOs. Vegetable cultivation in the homestead created employment opportunity for women as they participated most of the activities and spent considerable time in different activities needed for vegetable cultivation. For successful vegetable production, smooth supply of good seeds and satisfactory price of the products is essential. Supervision of the activities of respective organizations should be intensified. Recognition of women participation in income earning activities must be ensured nationally so that women become encouraged to contribute more.

\section{References}

BBS 2005. Statistical Year Book of Bangladesh 2005. Bangladesh Bureau of Statistics, Ministry of Planning, Government of People's Republic of Bangladesh.

BRAC 1999. Annual Report 1999. Yearly Publication of BRAC.

GOB 1999. Bangladesh Gazette. Government of the People's Republic of Bangladesh, Dhaka, Bangladesh (10/11/1999).

Haque, A. 1998. Impact of Rural Development Programme of BRAC on Social Well being of Women in a Selected Area of Mymensingh District. M.S. Thesis, Department of Agricultural Economics, BAU, Mymensingh

OXFORD. 2000. Human Development in South Asia 2000. OXFORD University Press, Great Clarendon Street, Oxford ox2 6DP: $p 213$

Rahman, M.Z. 1998. Impact of Rural Development Programme of BRAC on Household Income Generation through Increased Women's Participation in a Selected Area of Mymensingh District. M.S. Thesis, Department of Agricultural Economics, BAU, Mymensingh. 